\section{RECEIVED:}

20 March 2020

ACCEPTED:

20 April 2020

RELEASED:

20 July 2020
UDC 005.95:005.336.1

DOI 10.26661/2522-1566/2020-2/12-02

\title{
DEVELOPMENT AND IMPLEMENTATION OF A STRATEGIC PERSONNEL MANAGEMENT SYSTEM ACCORDING TO GOALS BASED ON KEY PERFORMANCE INDICATORS
}

\author{
Andrii Karpenko \\ National University \\ "Zaporizhzhia Polytechnic" \\ Zaporizhzhia, Ukraine \\ ORCID ID: 0000-0002-5717-4349
}

\author{
Natalia Karpenko \\ National University \\ "Zaporizhzhia Polytechnic" \\ Zaporizhzhia, Ukraine \\ ORCID ID: 0000-0002-9301-3649
}

\author{
Oleksandr Shudrik \\ National University \\ "Zaporizhzhia Polytechnic" \\ Zaporizhzhia, Ukraine \\ ORCID ID: 0000-0002-2343-347X
}

*Corresponding author email: andreykarpenko@ukr.net

\begin{abstract}
In the conditions of competition and difficult economic situation, domestic thermal power companies face problems of ensuring their own efficient activity. This is significantly due to the low motivation of the company staff and its productivity. Therefore, an important direction for improving the performance of such businesses will be to create an effective system of direct material incentives for employees, especially with regard to optional bonuses or targeted bonuses based on the use of the KPI. The study is aimed at the development of a strategic personnel management system according to goals based on key performance indicators. The article proposes an approach to developing a Management by Objects (MBO) system based on absolute and relative numerical indicators of the Key Performance Indicators (KPI) performance of the organization as a whole and the decomposition of goals at the level of individual business processes and functional responsibilities of the units. Methodology: In the course of the research general, scientific, theoretical and empirical methods were used, among which are the following: analysis and generalization of literature on the research topic, methods of observation and comparison, structural methods, methods of coordination and formalization, graphical and tabular representation of data. The theoretical and practical database of the strategic personnel management system according to goals is considered as an information base of the research. The scientific significance of the work is that the issue of developing such a system for a municipal enterprise is covered, whose activity depends on the regulatory policy of the state. The role of key performance indicators of KPI is determined as an effective tool in the system of direct material incentives, which assesses the efficiency and effectiveness of business processes, actions and functions of management, specific production, technological and other activities. The reasons that makes it impossible to use KPI without a comprehensive program for improving the personnel management system are analyzed and identified. The practical significance of the results of the study is that a detailed step-by-step scheme for improving the personnel management system is proposed, which will enable the development and implementation of the KPI system to be developed. The use of KPI in the strategic personnel management system will allow the manager to better control the processes of operating activities, create real indicators of the implementation of the enterprise strategy and improve productivity.
\end{abstract}


Karpenko, A., Karpenko, N. and Shudrik, O. (2020), "Development and implementation of a strategic personnel management system according to goals based on key performance indicators", Management and entrepreneurship: trends of development, Vol. 2, Issue 12, pp. 22-35, available at: https://doi.org/10.26661/2522-1566/2020-2/12-02

Keywords: strategy, key performance indicators, management to goals, personnel.

JEL Classification: A13, D20, L10, M12.

\section{INTRODUCTION}

The reform of the housing and utilities sector in the context of European integration forces domestic heat power companies to improve their activities. The problem of the availability, development and implementation of a strategy for their development is being raised more and more often, which implies increasing the efficiency of activities based on the growth in the volume and quality of housing and utility services. These tasks are complicated by the lack of regulatory documents and state mechanisms for implementing modern personnel management systems at heat power plants that are subordinate to local self-government bodies. The specifics of forming tariffs by the main type of economic activity of such enterprises are determined by the requirements of the national commission that carries out state regulation in the fields of energy and utilities on the principle of reaching the break-even point. This approach makes it impossible to create an additional fund for the system of direct financial incentives. Therefore, one of the main tasks to achieve the strategic goals of a municipal enterprise is to develop an effective system of direct material incentives for employees, especially in terms of non-mandatory payments or targeted bonuses, which is based on the use of a system of key performance indicators (KPI).

\section{LITERATURE REVIEW}

Development and implementation of a management system according to goals "Management by objectives" (MBO) using key performance indicators (KPI), today refers to the most common approaches of modern strategic personnel management. Peter Drucker (2008) is the founder of the MBO "management by goals", which was later refined by R. Kaplan and D. Norton (1996), D. Hope and R. Fraser (2003). Modern ideas and tools for the implementation of this system are presented in the works of many economists and specialists in human resource management, among which the research of K.K. Klochkov (2009) and P. R. Niven (2003) deserves special attention.

Most of the researches do not present the detailed comprehensive approach and practical recommendations for improving the management of personnel of a municipal-owned enterprise, which is necessary for the development and implementation of the strategic management system by goals based on key performance indicators.

\section{PAPER OBJECTIVE}

The purpose of the study development of a strategic personnel management system according to goals based on key performance indicators

\section{METHODOLOGY}

In the course of the research general, scientific, theoretical and empirical methods were used, among which are the following: analysis and generalization of literature on the research topic, methods of observation and comparison, structural methods, methods of coordination and formalization, graphical and tabular representation of data. The theoretical and practical database of the strategic personnel management system according to goals is considered as an information base of the research.

\section{RESULTS AND DISCUSSION}

To develop a system of strategic personnel management of an enterprise that would allow 
evaluating the effectiveness of operational activities and the development and implementation of a strategy, we consider the concept of personnel management by results or goals, which was developed by the American economist Peter Drucker back in the 50s of the XX century. (P. Drucker and J. Maciariello, 2008). This concept - Management by Objects (MBO) - is a system that is the basis of the philosophy of top managers, since it is recognized as one of the best approaches to personnel management and allows you to detect the goals and performance criteria of employees, individual departments or the entire organization and coordinate common resources to achieve the goals that are put forward.

The basis of this method (goal management system) consists of five main principles:

- goals are developed both for the organization and for each of its employees (they are consistent with the goals of the organization);

- goals are developed "top-down" to ensure communication with the strategy and "bottomup" to achieve relevance with employees;

- it is mandatory to involve employees in joint work with the superior to make decisions;

- qualitative assessment of the work done and constant feedback;

- all goals must comply with the "SMART" rule so that they can be used to build an effective system of staff motivation.

Among these principles, the most important for strategy development is the setting of intermediate goals, since they help the organization to consistently implement the developed strategy in accordance with the company's mission (M. Crumpton, 2015). To generate goals, it is used the SMART rule, whose name comes from the first letters of the goal setting criteria: Specific (specific); Measurable (measurable); Agreed (agreed); Realistic (real) or Relevant (relevant, correlates with other tasks); Timed (determined by time) (G. Doran, 1981).

The main drawback of the MBO was the absense of correlation between the system and the strategy, so in 1992 the goal management system was modified by D. P. Norton and R. S. Kaplan based on the developed balanced scorecard (BSC) (R. Kaplan and D. Norton, 1996). This system includes blocks of balanced (linked) indicators of both financial and non-financial nature, and allows you to assess the degree of achievement of goals in terms of 4 perspectives: finance; clients; internal processes; growth and development (Figure 1) (R. Kaplan and D. Norton, 2001).

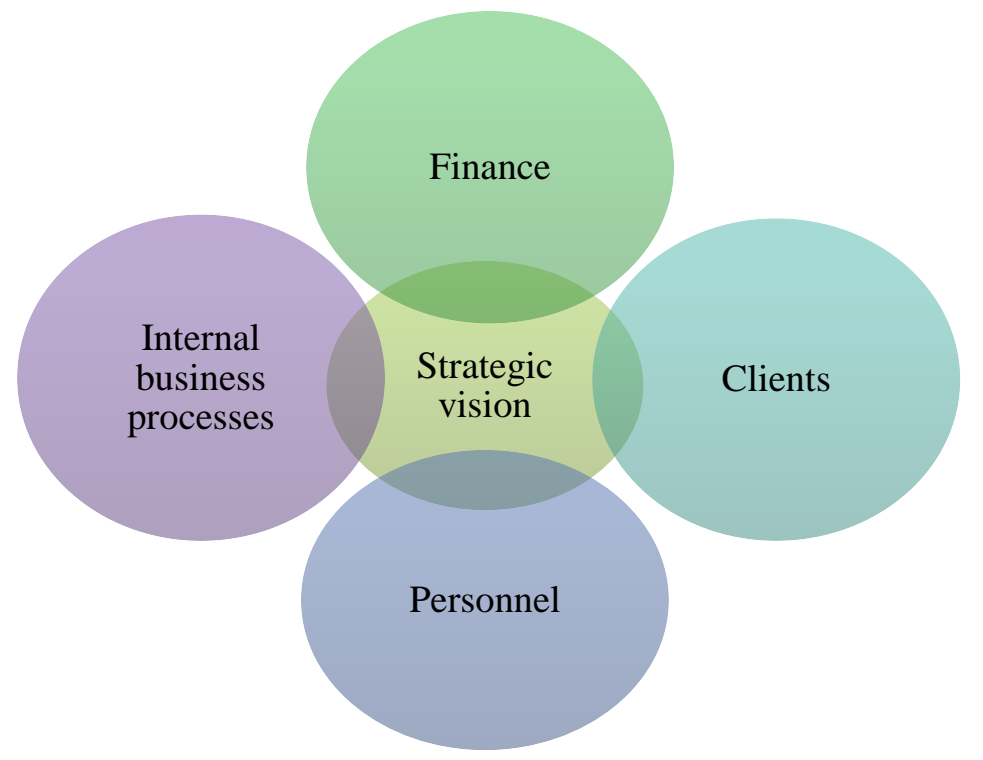

Figure 1. The company's prospects by the balanced scorecard 
Karpenko, A., Karpenko, N. and Shudrik, O. (2020), "Development and implementation of a strategic personnel management system according to goals based on key performance indicators", Management and entrepreneurship: trends of development, Vol. 2, Issue 12, pp. 22-35, available at: https://doi.org/10.26661/2522-1566/2020-2/12-02

Thus, the MBO was supplemented with a system of balanced indicators (each of the perspectives corresponds to its own set of targets), which allow combining the strategic vision with a system of key performance indicators (KPI). The result is a tool (KPI) that helps you to measure the strategic and operational performance of your business, its effectiveness, and solve motivation problems (O. Doronina, 2018).

Accordingly the developed system is based on the overlapping of the system and process approaches to management and includes the features of two methods, proving the relationship between the employee motivation and the efficiency of the enterprise as a whole (J. Hope and R. Fraser, 2003). In other words, the use of the KPI system allows employees to focus on solving operational tasks and achieving the company's strategic goals.

Since the system of balanced indicators developed by D. P. Norton and R. S. Kaplan was focused only on the strategy and indicators for the large western enterprises of private ownership, many economists and scientists were interested in adapting it for enterprises of other forms of ownership (the state budget, non-for-profit companies, self-supporting municipal services, etc.) and other market segments (small and medium-sized businesses), as well as adjusting the system to the specifics of national economies and the legal sphere.

One of the researchers who worked on developing the system of key performance indicators (KPI) for state and non-profit enterprises in the context of a balanced scorecard was P. G. Niven (P. Niven, 2003). However, his adapted system is also focused mainly on western practice, which does not take into account the realities of the domestic economy and can not be used by municipal heat power enterprises without adaptation and refinement. And only in 2010, the leading economist and consulting expert A. K. Klochkov proposed the system of key performance indicators (KPI) for private companies adapted to the conditions of the CIS countries (A. Klochkov, 2009).

Based on the information from the studied sources, it can be concluded that in order to develop and implement a goal-based management system based on KPI at domestic enterprises, it is necessary to correctly adapt the national economy and legislation (M. Burbridge, 2009). To implement it at the enterprise, it is necessary to improve, unify and optimize the existing personnel management system.

Based on the research the authors propose to improve the system of strategic personnel management of a municipal heat power enterprise using key performance indicators in the form of a scheme (Table 1).

The first phase is creating and agreeing upon the strategic vision of changes and their need, analyzing the existing systems of personnel management, holding a strategic session with CEO and top managers on the creation of centers of responsibility for change and the group of innovators.

The analysis makes it possible to identify the need to adjust and unify the organizational structure; regulations on divisions; job descriptions; and regulation of business processes.

After detecting inconsistencies in existing regulatory documents, a communication map is developed, which is a tool for optimizing business processes and a form of visualization of distribution of information flows in the company, of control points of information peak, of distribution of responsibility for various business processes, of distribution of functional load of departments. In other words, the communication map is the basis for further description of business processes, because it represents the functional load in detail.

The development of a communication map with detailed functional responsibilities makes it easy to analyze the work performed to determine the functional load on the specialist within the company's tasks and to normalize them. Its use is aimed at identifying "bottlenecks", eliminating duplication of functions, standardizing and optimizing the organizational structure, and establishing internal communications of divisions. 
Scheme of implementation of the KPI system

at the municipal enterprise of heat power engineering

\begin{tabular}{|c|c|}
\hline №n/ா/ா & Measures to implement the KPI system \\
\hline 1 & Development of a communication (functional) map \\
\hline 1.1 & Conducting a survey of employees of the company (3150 staff units) \\
\hline 1.2 & Processing of questionnaire data \\
\hline 1,3 & Processing information with line managers \\
\hline 1.4 & Rationing time for performing functional duties \\
\hline 1.5 & Identification of the main functional responsibilities of divisions \\
\hline 1.6 & Identify the necessary communication links between divisions \\
\hline 2 & Regulation of business processes \\
\hline 2.1 & Identification and description of the main processes \\
\hline 2.2 & Development of a (causal) process map \\
\hline 2.3 & Development of regulations (orders) for the implementation of business processes \\
\hline 3 & The development of an optimal organizational structure \\
\hline 3.1 & $\begin{array}{l}\text { Development of proposals for making changes to the organizational structure and } \\
\text { reallocation of functional responsibilities of divisions to optimize business processes and } \\
\text { improve labor efficiency. }\end{array}$ \\
\hline 3.2 & Standardization of the structure \\
\hline 3.3 & The adjustment of the organizational structure \\
\hline 4 & Developing job descriptions \\
\hline 4.1 & Adjustment of main and additional job responsibilities \\
\hline 4.2 & Setting personal goals for positions \\
\hline 4.3 & Description of the position communications \\
\hline 5 & Description of the communications position \\
\hline 5.1 & Adjusting the main and additional division assignments \\
\hline 5.2 & Setting goals for divisions \\
\hline 5.3 & Description of department communications \\
\hline 6 & Development of bonus targets \\
\hline 6.1 & Conducting strategic sessions with TOP managers \\
\hline 6.2 & Selecting key goals for the functional responsibilities of divisions \\
\hline 6.3 & $\begin{array}{l}\text { Calculating the weight of the impact of selected indicators on the financial result of the } \\
\text { enterprise }\end{array}$ \\
\hline 6.4 & The development of the goal tree \\
\hline 6.5 & Certification of indicators \\
\hline 6.6 & Analysis of indicators using the benchmarking method \\
\hline 6.7 & Setting the limit values and the step to achieve the target values of indicators \\
\hline 7 & Introduction of the KPI system \\
\hline 7.1 & Correction of existing regulatory documents regulating the system of financial incentives \\
\hline 7.2 & Development and approval of the Order on the introduction of the KPI system \\
\hline 7.3 & Development of informational posters \\
\hline 7.4 & Conducting strategic sessions with line managers \\
\hline
\end{tabular}

Source: Own development

The information on functional responsibilities is performed through a survey of all employees of the enterprise (Figure 2). 
Karpenko, A., Karpenko, N. and Shudrik, O. (2020), "Development and implementation of a strategic personnel management system according to goals based on key performance indicators", Management and entrepreneurship: trends of development, Vol. 2, Issue 12, pp. 22-35, available at: https://doi.org/10.26661/2522-1566/2020-2/12-02

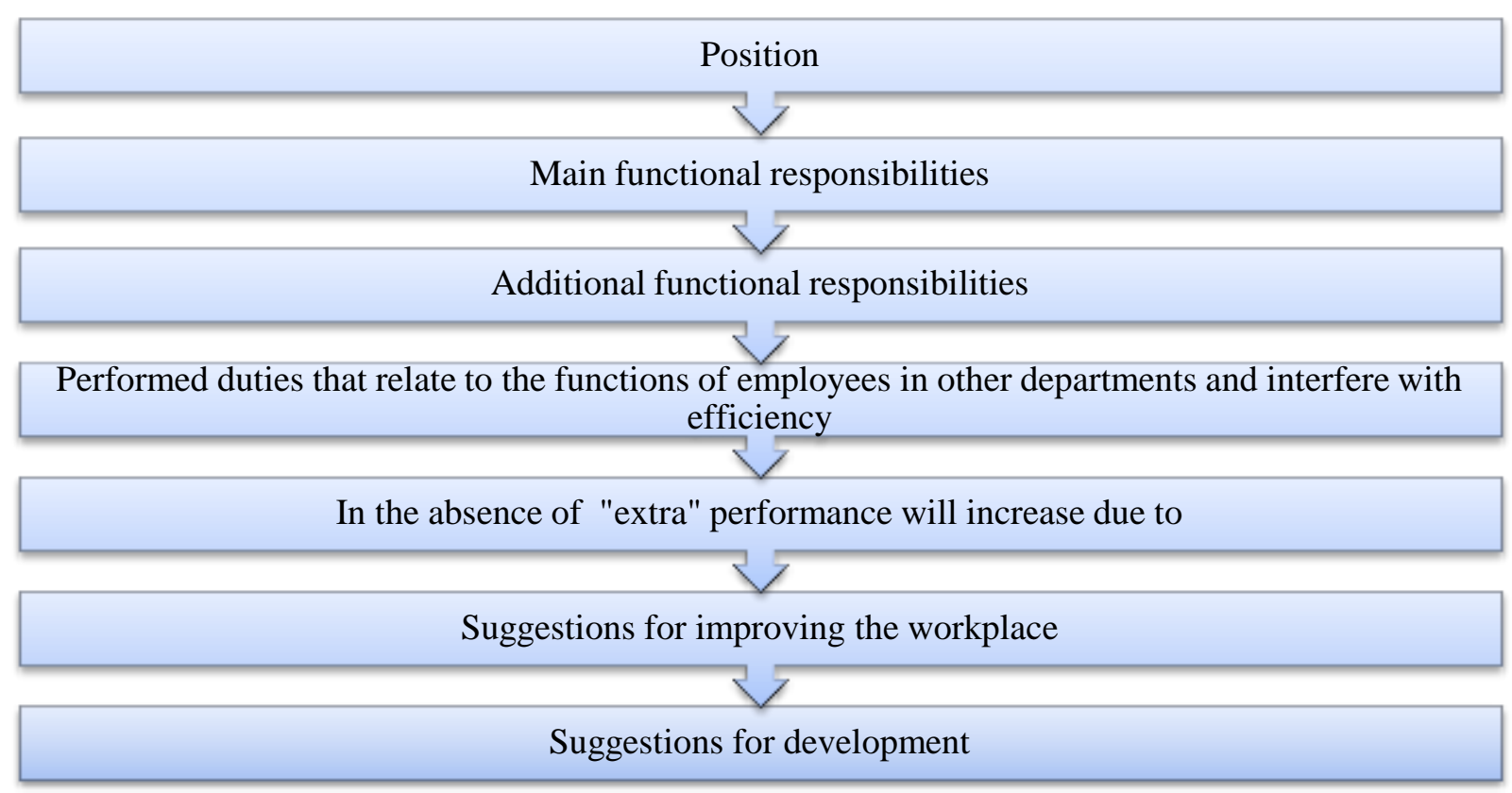

Figure 2. Questionnaire for developing a functional map

\section{Source: Own development}

The processing involves the execution of several standard procedures: digitizing the collected data; synthesis of all collected questionnaires for primary and additional responsibilities of one position, their unification in a single communication and functional sheet; processing profiles with line managers to establish the best and the worst case execution time of operations (min-max), the frequency of execution of work (annually, semiannually, quarterly, weekly, daily, etc.); substantiation of necessity of work performance (regulations, rules, orders); establishing communication links with other departments; rationing FEC (full-time employment) work time by the quartile method.

After processing the questionnaires, the actual functional responsibilities of the divisions are formed from the information received and their workload is calculated.

A communication map is formed from the communication data, which in turn is overlapped with the functional map and forms the communication and functional map of the enterprise (A. Karpenko and A. Shudrik, 2018).

The second stage is the regulation of business processes, which provides the development of business processes models of functional responsibilities and the creation of regulations, updating instructions.

Noteworthy is the approach (R. Kaplan and D. Norton, 1996), according to which seven types of business processes and the main functions of each group are defined:

- input main processes ensure timely delivery and storage of components necessary for the main production, their timely transfer to production and processing with minimal material and time costs;

- production business processes ensure the production of the main types of products with the lowest cost of time and finance, as well as the move of products to the warehouse;

- outgoing business processes are aimed at selling, storing and shipping the main type of products with minimal time and cost, as well as meeting the needs of the buyer;

- business processes of the 1st kind, aimed at ensuring the normal functioning of the main and additional business processes; 
- business processes of the 2 nd kind, aimed at ensuring the normal functioning of business processes of management;

- tactical business processes focused on tactical enterprise management, development of management decisions for specific types of enterprise activities;

- strategic business processes providing strategic management of the enterprise, development of ways to develop the enterprise.

Today, modern enterprises distinguish three groups of processes: end-to-end processes that occur in several divisions of the enterprise and cross the boundaries of functional divisions; processes of divisions which activities are limited to one functional division; operations of the lowest level of decomposition of the enterprise's activities.

Processes can be characterized by several groups of indicators: process indicators are numerical values that characterize the course of the process and its costs (time, financial, resource, human, etc.); result indicators are numerical values that characterize the product (service) as a result of the process (the absolute volume of services, the volume of services relative to the ordered or required, the number of errors and failures in the provision of services, the measure of product compliance with requirements, etc.); customer satisfaction indicators.

Based on the data received, the information about existing and new business processes is generated in the form of a "process map" reflecting all business processes and their relationship. Business processes are also classified, resulting in the development of business goals and policies, and implementation of the planning strategy.

Process identification is performed according to the business process description model, which consists of: the process name; the process code; the content, goals, functions, the place of this process among other processes, the order of execution of the process in the form of a flowchart or algorithm; the owner of the process; standards, entry and exit points, resources and parameters that are measured; planned indicators; necessary resources (J. Hope and R. Fraser, 2003).

Relationships are established between the types of activities (functions of divisions) and their reflection - processes. Identification is provided based on the coincidence of goals, as well as the coincidence of other features - input and output flows, management actions, resources used, and so on.

The business process regulation is the main document that explains to employees how to complete the process, requirements for inputs/outputs, requirements for activities, management and responsibility for the business process. The rules of the business process are to be understandable and useful to end-users. As an additional tool for understanding the business process, business process maps are attached to the regulations.

In general, the regulations may consist of 6 sections and appendices:

- the first section "Business Process Assignment" describes the purpose and scope of the regulations;

- the second section "Terms and Definitions" forms the conceptual apparatus of the regulations;

- the third section "Process Boundaries" presents the limitations of the scope of the business process, clearly indicates its boundaries;

- the fourth section "Business Process Management" is intended for managers and the person responsible for the process, since it describes the plan, measures to control and directions for improving the business process;

- the fifth section "Structure of the Business Process" forms an idea of the structure and responsibility within the business process for the person responsible for the process and its participants;

- the sixth section "Description of the Business Process" contains the general description of the process and the description of sub-processes for the performers to achieve maximum success.

The result of the regulation stage is to identify the main processes, model and create 
Karpenko, A., Karpenko, N. and Shudrik, O. (2020), "Development and implementation of a strategic personnel management system according to goals based on key performance indicators", Management and entrepreneurship: trends of development, Vol. 2, Issue 12, pp. 22-35, available at: https://doi.org/10.26661/2522-1566/2020-2/12-02

regulations, instructions, and develop a (causal) process map.

At the third stage standardization and optimization of the organizational structure is performed according to the functional responsibilities and goals of business processes, which involves the following works: standardization of organizational structures; development of organizational structure diagrams.

The fourth stage ensures the development of job descriptions and provisions on subdivisions and the main tasks include: adjustment of basic and additional duties; adjustment of the primary and secondary purpose units.

It is only after standardization, description of business processes and definition of actual functional responsibilities of divisions that we can proceed to the fifth stage of developing the system of direct material motivation based on key performance indicators. Accordingly, the following main activities are carried out: conducting strategic sessions with TOP managers to set goals and create an updated tactical and strategic vision based on communication and functional and strategic maps; selecting key goals of functional tasks of divisions; developing the tree of goals; establishing a procedure for calculating indicators; assigning of a person responsible for calculating; assigning of a person responsible for submitting the certificate on awarding; assigning of a person responsible for negotiating of award; preparing of the passport of the indicator, matching the head.

The established system of indicators is included in the current Regulation on direct financial incentives or targeted bonuses, and regulations and orders are developed .

One of the latest methodological concepts of strategic personnel management is the methodology for developing "strategic maps" (S. Patil and R. Kant, 2012; R. Gashi, 2013). The map is built on a hierarchical basis. All the goals, sub-goals and tasks of the entire enterprise team are built in the map and are reflected in four perspectives - all the actions of the staff are interconnected and have indicators that show how the plan is being implemented, how fast the goals are being achieved (P. Niven, 2003). So, a strategic map is a fairly simple and visual way to reflect the organization's strategy, visualize the goals and objectives of the staff in the context of four development perspectives (finance; clients; internal processes; growth and development). The functional purpose of strategic maps is to create a unified strategic vision for management, distribute the strategy among employees of the enterprise and transfer it to the operational level of activity, that is, to daily operational processes. The strategic map is a document that begins the development of the goals tree and further implementation of the personnel management system according to goals.

The main strategic objective of the Concern "Miski Teplovi merezhi", which has the strategy map developed, is to reach a breakeven point and to create conditions for income generation that will improve financial stability by improving its competitiveness. The strategic goal is the general target that the activity of the enterprise manager is aimed at, it is the main reference point and indicator of the efficiency and effectiveness of the entire enterprise team.

The implementation of the strategic goal will allow us to fulfill the mission of the enterprise established by the city Council, namely, maintaining the centralized heat supply system of the city of Zaporizhzhia, providing reliable, high-quality heating and hot water services, and reducing the financial burden on the city budget. This will reduce social tension by approving transparent social tariffs, reduce the cost of production and thereby improve the financial condition of this business entity, and the company's staff - decent compensation, which will encourage them to realize their professional and creative potential. Based on the objectives of the global strategy of the entity under study, within the framework of building a strategic map, goals for its four main projections are formed and cause-and-effect relationship between them is determined.

At the top level of the strategic map, there is a projection "Finance", which covers the whole range of measures to increase profitability and reduce expenses, and cost of services. Cost reduction is possible by approving reasonable tariffs for services, reducing production, transportation and sales costs, reducing costs associated with recalculations for low-quality services and losses for non-provision of services, reducing costs associated with penalties and compensation payments. 
A level lower is the "Customers" perspective, which is considered as the consumer base and market segment in which the entity operates. The projection covers the goals of increasing the customer base by retaining existing and attracting new customers to sell main products, and entering the market by diversifying services, performing system analysis (social and marketing research) and creating a unified consumer base.

Internal business processes perspective is aimed at reaching the following goals: diversification of services to expand the activities offered to perform services for the maintenance of internal networks of residential buildings, to perform metrological services such as verification, configuration and repair of heat meters and water meters; development of project and budget documentation at the design bureau, work on the foreign market.

The "Personnel" projection is the center of the strategic map, since all business processes are performed by personnel, whose productivity determines the efficiency of the enterprise (Figure 3).

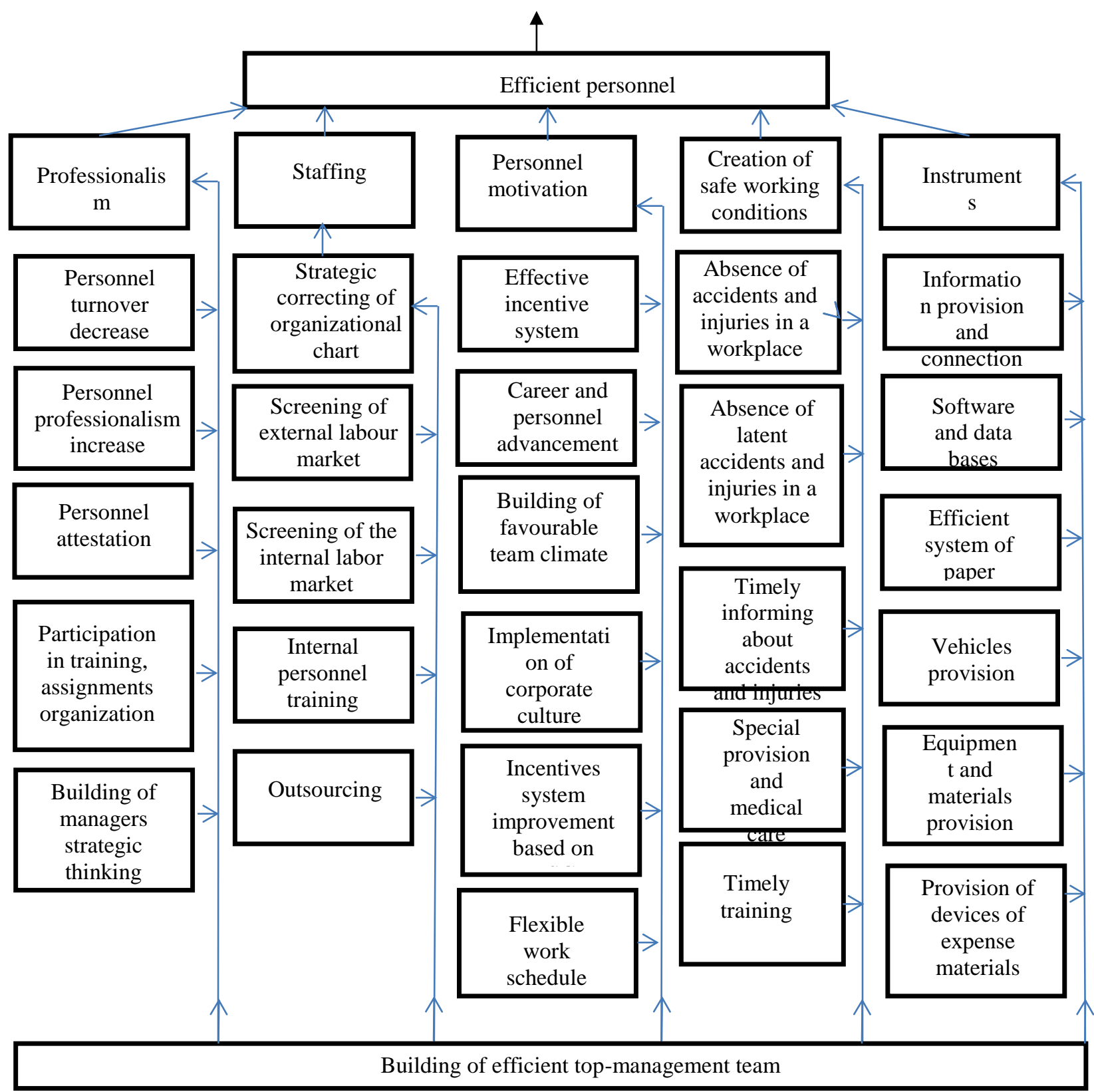

Figure 3. Projection "Personnel" of the strategic map of the Concern "Miski Teplovi Merezhi" 
Karpenko, A., Karpenko, N. and Shudrik, O. (2020), "Development and implementation of a strategic personnel management system according to goals based on key performance indicators", Management and entrepreneurship: trends of development, Vol. 2, Issue 12, pp. 22-35, available at: https://doi.org/10.26661/2522-1566/2020-2/12-02

That is why the main goal of this projection is to create an effective workforce, which is achieved by implementing a number of objectives: improving the professionalism of employees; staffing; motivation of staff; creating safe working conditions. It is necessary to build a team of top managers that will develop and implement a strategy for each of the perspectives and tasks.

Based on the developed strategic map, one can proceed to the tree of goals, which will allow to formalize the strategy directions to specific indicators and the address belonging of these indicators to structural divisions and performers (D. Hussey, 1998; V. Robinson, 2007). In other words, the formation of the tree of goals (tree-whole) is making a structured hierarchical list of enterprise goals, in which lower level goals are subordinate and serve to achieve higher level goals within the framework of strategic management.

To sum it up, we can note that the development of a strategic map, which is formalized by the goal management system based on KPI, is supported by material incentives. For the company's administration, it can become a very effective tool for managing financial indicators and staff motivation. This can be achieved by conscious spreading a certain system among managers at various levels and all employees, by defining their place and role in specific business processes, understanding what specific financial results are affected by their work, and by gradually accepting the goals of the company (enterprise) for their goals.

In general, strategic management requires a well-established goal-setting mechanism, that includes logical progression from a more abstract general foresight to concrete forecasting and further programming. Strategic management allows to consciously plan and choose priority areas of development in the four areas of BSC, coordinate and establish teamwork of top managers of the company to achieve the overall result.

\section{CONCLUSION}

The lack of a regulatory and methodological framework for managing by goals today restricts the use of appropriate tools at state and municipal enterprises. Using modern tools for management by goals in practice requires a complex creative individual approach, which includes five stages: 1) audit of the existing personnel management system, formation of strategic vision of changes in the company's management, creation of a change implementation center and a cross-functional group of innovators; 2) improvement of the existing personnel management system (in terms of: optimization and standardization of the organizational structure; reallocation and assignment of additional and cross-functional responsibilities to responsible persons; elimination of duplication of functional responsibilities and "bottlenecks" in business processes; transition from a formal approach to the real use of job descriptions and regulations at departments; identification of real workload of divisions through optimization of existing business processes; 3)adaptation of existing tools for management by goals and development of unique KPI; 4) monitoring the performance of indicators and feedback from staff; 5) using a strategic approach to management and mandatory connection of the selected strategy with specific goals and KPI of divisions.

A goal-based management system using KPI has been implemented at the municipal heat power company that can ensure: compliance with the principles of objectivity (assessment of labor contribution), timeliness (minimizing the gap between labor results and receiving incentives), noticeability (effectiveness of the bonus), transparency (accessibility of the remuneration system provision). Its main distinctive features are: targeted affiliation in relation to each individual business process, decomposition to the level of line managers and performers, clarity, ease of measurement and correlation of indicators, which contributes to the individual motivation of each employee, certainty in labor functions. 


\section{REFERENCES}

Burbridge, M. (2009), "HR professionals share talent management views", Strategic HR Review, Vol. 8(4), available at: https://doi.org/10.1108/shr.2009.37208dab.006 (Accessed 01 March 2020), DOI: $10.1108 / \mathrm{shr} .2009 .37208$ dab.006

Crumpton, M. A. (2015), “The strategic planning process", Strategic Human Resources Planning for Academic Libraries, pp. 13-22, available at: https://doi.org/10.1016/B978-1-84334-7644.00002-2 (Accessed 12 March 2020), DOI: 10.1016/B978-1-84334-764-4.00002-2

Hope, J. and Fraser, R. (2003), Beyond Budgeting: How Managers Can Break Free from the Annual Performance Trap, Harvard Business Press, 256 p.

Hussey, D. (1998), "Strategic planning for human resources", Strategic Management, pp. 432-461, available at: https://doi.org/10.1016/b978-0-7506-3849-4.50025-2 (Accessed 02 March 2020), DOI: $10.1016 / \mathrm{b} 978-0-7506-3849-4.50025-2$

Doran, G. T. (1981), "There's a S.M.A.R.T. way to write management's goals and objectives", Management Review, Vol. 70, Issue 11 (AMA FORUM), pp. 35-36, available at: https://community.mis.temple.edu/mis0855002fall2015/files/2015/10/S.M.A.R.T-WayManagement-Review.pdf (Accessed 03 March 2020).

Doronina, O. (2018), "Transformation of approaches to personnel's motivation in the conditions of the newest managerial paradigm", Management and Entrepreneurship: Trends of Development, Vol. 3(05), pp. 23-32, available at: https://managementjournal.org.ua/index.php/journal/article/view/63/55 (Accessed 02 March 2020), (in Ukranian).

Drucker, P. F. and Maciariello, J. A. (2008), Management, Collins, 568 p.

Gashi, R. (2013), "Strategic Human Resources Management: Human Resources or Human Capital”, Academic Journal of Interdisciplinary Studies, available at: https://doi.org/10.5901/ajis.2013.v2n9p88 (Accessed 02 March 2020), DOI: 10.5901/ajis.2013.v2n9p88

Kaplan, R. S. and Norton, D. P. (1996), The Balanced Scorecard: Translating Strategy into Action, Harvard Business Press, $322 \mathrm{p}$.

Kaplan, R. S. and Norton, D. P. (2001), The Strategy-Focused Organization: How Balanced Scorecard Companies Thrive in the New Business Environment, Harvard Business School Press.

Karpenko, A. V. and Shudrik, A. Yu. (2018), "Functional communication card as a tool for optimizing the company's business processes", Sbornik materialov I mezhdunarodnoj nauchno-prakticheskoj konferencii [Abstracts of scientific works of I international scientificpractical conference], Innovacionnoe razvitie ekonomiki $\mathrm{v}$ kontekste formirovaniya nacionalnoj bezopasnosti [Innovative economic development in the context of forming national security], Baranovichi, 15-16 March 2018, Baranovichi: BarGU, pp. 56-58, available at:

https://rep.polessu.by/bitstream/123456789/16335/1/Vasil\%27chenko_AO_Problemy\%20i\%2 Operspektivy\%20razvitiia\%20turizma\%20v\%20kontekste\%20formirovaniia\%20imidzha\%20 Respubliki\%20Belarus\%27\%20na\%20mezhdunarodnoi\%20arene.pdf (Accessed 10 March 2020), (in Russian).

Klochkov, A. K. (2009), KPI i motivaciya personala. Polnyj sbornik prakticheskih instrumentov [KPI and staff motivation. Complete collection of practical tools], EKSMO, Moscow, (in Russian).

Niven, P. R. (2003), Balanced Scorecard Step-by-Step for Government and Nonprofit Agencies. John. Wiley \& Sons. 320 p.

Patil, S. K. and Kant, R. (2012), "Organizational culture a HR strategy for successful knowledge management”, Strategic HR Review, Vol. 11(6), pp. 322-328, available at: 
Karpenko, A., Karpenko, N. and Shudrik, O. (2020), "Development and implementation of a strategic personnel management system according to goals based on key performance indicators", Management and entrepreneurship: trends of development, Vol. 2, Issue 12, pp. 22-35, available at: https://doi.org/10.26661/2522-1566/2020-2/12-02

$\underline{\text { https://doi.org/10.1108/14754391211264785 }}$ (Accessed 03 March 2020), DOI: $10.1108 / 14754391211264785$

Robinson, V. (2007), "Is contemporary HR management strategic?", Strategic HR Review, Vol. 7(1), available at: https://doi.org/10.1108/shr.2008.37207aaf.005 (Accessed 03 March 2020), DOI: 10.1108/shr.2008.37207aaf.005

\section{СПИСОК ВИКОРИСТАНИХ ДЖЕРЕЛ}

Burbridge M. HR professionals share talent management views. Strategic HR Review. 2009, 8(4). DOI: 10.1108/shr.2009.37208dab.006 (дата звернення: 01.03.2020).

Crumpton M. A. The strategic planning process. Strategic Human Resources Planning for Academic Libraries. 2015, pp. 13-22. DOI: 10.1016/b978-1-84334-764-4.00002-2 (дата звернення: 12.03.2020).

Hope J. and Fraser R. Beyond Budgeting: How Managers Can Break Free from the Annual Performance Trap. Harvard Business Press. 2003, 256 p.

Hussey D. Strategic planning for human resources. Strategic Management. 1998, pp. 432-461. DOI: 10.1016/b978-0-7506-3849-4.50025-2 (дата звернення: 02.03.2020).

Doran G. T. There's a S.M.A.R.T. way to write management's goals and objectives. Management Review. Volume 70. Issue 11 (AMA FORUM). 1981, pp. 35-36. URL: https://community.mis.temple.edu/mis0855002fall2015/files/2015/10/S.M.A.R.T-WayManagement-Review.pdf (дата звернення: 03.03.2020).

Дороніна О. А. Трансформація підходів до мотивування персоналу в умовах новітньої управлінської парадигми. Менеджмент та підприємниитво: тренди розвитку. Електронне наукове видання. 2018. 3(05). C. 23-32. URL: https://managementjournal.org.ua/index.php/journal/article/view/63/55 (дата звернення: 02.03.2020).

Drucker P. F. and Maciariello J. A. Management. Collins. 2008. 568 p.

Gashi R. Strategic Human Resources Management: Human Resources or Human Capital. Academic Journal of Interdisciplinary Studies. 2013. DOI: 10.5901/ajis.2013.v2n9p88 (дата звернення: 02.03.2020).

Kaplan R. S. and Norton D. P. The Balanced Scorecard: Translating Strategy into Action. Harvard Business Press. 1996. 322 p.

Kaplan R. S. and Norton D. P. The Strategy-Focused Organization: How Balanced Scorecard Companies Thrive in the New Business Environment. Harvard Business School Press. 2001.

Карпенко А. В., Шудрик А. Ю. Функционально-коммуникационная карта как инструмент оптимизации бизнес-процессов компании. Инноваџионное развитие экономики в контексте формирования национальной безопасности : сборник материалов I международной научно-практической конференции (Барановичи, 15-16 марта 2018 года). Барановичи: БарГУ. 2018. С. 56-58. URL: https://rep.polessu.by/bitstream/123456789/16335/1/Vasil\%27chenko_AO_Problemy\%20i\%2 0perspektivy\%20razvitiia\%20turizma\%20v\%20kontekste\%20formirovaniia\%20imidzha\%20 Respubliki\%20Belarus\%27\%20na\%20mezhdunarodnoi\%20arene.pdf (дата звернення: 10.03.2020).

Клочков А. К. КРІ и мотивация персонала. Полный сборник практических инструментов. М.: ЭКСМО. 2009. $160 \mathrm{c}$.

Niven P. R. Balanced Scorecard Step-by-Step for Government and Nonprofit Agencies. John. Wiley \& Sons. 2003. 320 p.

Patil S. K. and Kant R. Organizational culture a HR strategy for successful knowledge management. Strategic HR Review. 2012. 11(6). pp. 322-328. DOI:10.1108/14754391211264785.

Robinson V. Is contemporary HR management strategic? Strategic HR Review. 2007. 7(1). DOI: 10.1108/shr.2008.37207aaf.005. 


\section{РОЗРОБКА ТА ВПРОВАДЖЕННЯ СИСТЕМИ СТРАТЕГІЧНОГО УПРАВЛІННЯ ПЕРСОНАЛОМ ЗА ЦІЛЯМИ НА ОСНОВІ КЛЮЧОВИХ ПОКАЗНИКІВ ЕФЕКТИВНОСТІ}

\author{
Карпенко Андрій \\ Володимирович \\ Національний університет \\ «Запорізька політехніка» \\ м. Запоріжжя, Україна
}

\author{
Карпенко Наталя \\ Миколаївна \\ Національний університет \\ «Запорізька політехніка» \\ м. Запоріжжся, Украӥна
}

\author{
Шудрик Олександр \\ Юрійович \\ Національний університет \\ «Запорізька політехніка», \\ Концерн «Міські теплові \\ мережі», Запоріжжя, Україна
}

У статті запропоновано підхід до розробки системи стратегічного управління персоналом за цілями (Management by objects - MBO), що виконується на основі абсолютних та відносних числових показників ефективності Key Performance Indicators (KPI) діяльності організації в цілому та декомпозиції цілей на рівні окремих бізнес-процесів і функціональних обов'язків підрозділів. Висвітлюється питання розробки такої системи для муніципального теплоенергетичного підприємства діяльність якого залежить від регуляторної політики держави. Визначається роль ключових показників ефективності KPI, як дієвого інструменту в системі прямого матеріального стимулювання за яким оцінюється ефективність та результативність бізнес-процесів, дій і функцій управління, конкретної виробничої, технологічної та іншої діяльності. Проведено аналіз існуючої ситуації та визначено причини, що унеможливлюють використання KPI без комплексної програми з вдосконалення системи управління персоналом. Запропоновано обгрунтовану детальну поетапну схему 3 вдосконалення системи управління персоналом, що надасть змогу перейти до розробки та впровадження системи KPI. Використання системи KPI у системі стратегічного управління персоналом за цілями дозволить керівнику краще контролювати процеси операційної діяльності, створити реальні індикатори реалізації стратегії підприємства та підвищити продуктивність праці.

Ключові слова: стратегія, ключові показники ефективності, управління за цілями, персонал.

\section{РАЗРАБОТКА И ВНЕДРЕНИЕ СИСТЕМЫ СТРАТЕГИЧЕСКОГО УПРАВЛЕНИЯ ПЕРСОНАЛОМ ПО ЦЕЛЯМ НА ОСНОВЕ КЛЮЧЕВЫХ ПОКАЗАТЕЛЕЙ ЭФФЕКТИВНОСТИ}

\section{Карпенко Андрей \\ Владимирович}

Национальный университет «Запорожская политехника»

г. Запорожье, Украина
Карпенко Наталья Николаевна

Национальный университет

«Запорожская политехника»

2. Запорожье, Украина
Шудрик Александр Юрьевич

Национальный университет «Запорожская политехника» Конщерн «Городские тепловые сети», г. Запорожье, Украина

В статье предложен подход к разработке системы стратегического управления персоналом по целям (Management by objects - MBO), выполняющийся на основе абсолютных и относительных числовых показателей эффективности Кеy Performance Indicators (KPI) деятельности организации в целом и декомпозиции целей на уровни отдельных бизнес-процессов и функциональных обязанностей подразделений. Освещается вопрос разработки такой системы для муниципального теплоэнергетического предприятия, деятельность которого зависит от регуляторной политики государства. Определяется роль ключевых показателей эффективности КРI, как действенного инструмента в системе прямого 
Karpenko, A., Karpenko, N. and Shudrik, O. (2020), "Development and implementation of a strategic personnel management system according to goals based on key performance indicators", Management and entrepreneurship: trends of development, Vol. 2, Issue 12, pp. 22-35, available at: https://doi.org/10.26661/2522-1566/2020-2/12-02

материального стимулирования, по которому оценивается эффективность и результативность бизнес-процессов, действий и функций управления, конкретной производственной, технологической и иной деятельности. Проведен анализ существующей ситуации и определены причины исключающие возможность использования КРI без комплексной программы по совершенствованию системы управления персоналом. Предложена обоснованная подробная поэтапная схема по совершенствованию системы управления персоналом, которая позволит перейти к разработке и внедрению системы КPI. Использование системы KPI в системе стратегического управления персоналом по целям позволит руководителю лучше контролировать процессы операционной деятельности, создать реальные индикаторы реализации стратегии предприятия и повысить производительность труда.

Ключевые слова: стратегия, ключевые показатели эффективности, управление по целям, персонал. 